\title{
Preceptorship Method To The Achievement Of New Nurse CompetenciesAt Rumah Sakit Islam Surabaya Jemursari
}

\author{
Yuliartiningsih \\ Airlangga University, yuliartiningsih-2016@fkp.unair.ac.id \\ Nursalam \\ Airlangga University, Surabaya \\ Yanis Kartini \\ Nahdlatul Ulama University Surabaya
}

\begin{abstract}
Competency issues and the lack of implementation of an orientation program with the preceptorship method are problems and require solutions / solutions. The purpose of the study explained the influence of the preceptorship method to the achievement of new nursecompetencies. The design of this study used quasyexperiment by conducting the pre-test and post-test stages in the treatment and control groups. The design of the analysis variable was obtained by twenty new nurses from different units in RSIS Jemursari and RSI Surabaya using total sampling. The independent variable is the preceptorship method and the dependent variable is the achievement of new nurse competencies. The research instrument uses a checklist of competencies for new nurses based on basic competencies according to SKKNI. Data analysis using Paired Sample t Test and Independent Sample $t$-Test with $\alpha=0.05$. achievement of the competency of new nurses before and after intervention in the treatment group and the control group obtained the Paired Sample $t$-Test value $=0,000<0,05$ means that there is a significant influence before and after it is done the method of preceptorship towards achieving the competence of new nurses. Before the intervention in the treatment group and the control group, the Independent Sample $t$-Test $=0.139$ $<0.05$ means that there is no difference between the treatment group and the control group, whereas after intervention in the treatment and control groups obtained Independent Sample $t$-Test $=0,000<0.05$ means that there is a difference between the treatment group and the control group after the preceptorship method is done. The preceptorship method is a determinant variable that influences the achievement of new nurse competencies. Suggestions for hospitals to improve the quality of HR (preceptor) and the competence of new nurses, it is necessary to provide training in $\mathrm{CE} /$ preceptor.
\end{abstract}

Keywords: Preceptorship, achievement ofnew nurses competencies.

\section{LATAR BELAKANG}

Perawat baru (fresh graduate) menghadapi kesulitan/ permasalahan saat memasuki dunia kerja (Douglas 1992). Permasalahan tersebut terkait tugas pokok dan fungsi (tupoksi) yang harus dikerjakan sehingga berpengaruh terhadap kinerja (Proulx \& Boucier 2008). Hasil penelitian Proulx \& Boucier (2008) dalam Maftukhah (2017) tentang permasalahan perawat baru pada saat bekerja selama masa trainee terkait dengan tupoksi antara lain kurang percaya 
diri dalam memberikan asuhan keperawatan, ketidakmampuan dalam mengambil keputusan disaat kritis, minim pengetahuan klinis, ketergantungan dengan perawat senior dalam menjalankan tugas, hubungan dengan rekan kerja, stressor dengan lingkungan kerja serta masalah komunikasi dengan dokter.

Perawat baru dalam mencapai kompetensi dalam kaitannya dengan pengaturan pendampingan di rumah sakit. Program dalam mendampingi perawat baru dengan metode preceptorship dapat dilakukan di rumah sakit pendidikan untuk meningkatkan kualitas perawat terutama perawat baru dan mahasiswa perawat karena sangat penting untuk keberhasilan dan kemajuan rumah sakit serta kompetensi dari perawat itu sendiri (Billay, Myrick \& Yonge, 2015).

Berdasarkan teori Nursalam (2008), program preceptorship merupakan alat sosialisasi dan orientasi. Model preceptorshipmerupakan metode rekrutmen staf baru. Perawat baru dapat memper-kirakan kondisi organisasi dan praktik klinik dapat diprediksi.Preceptee diharapkan akan memiliki kemampuan yang sama dengan preceptornya, sehingga diperlukan diskusi antara preceptor dan preceptee memberikan gambaran praktik dalam lingkungan kerja baru.Preceptor merupakan seorang perawat yang mem-berikan bimbingan dan arahan,memberikan inspirasi kepada rekanrekannya, menjadi panutan (role model), serta mendukung pertumbuhan dan perkembangan individu atau perawat baru (trainee) untuk jangka waktu tertentu dengan tujuan khhusus mengenalkan trainee terhadap pekerjaan barunya (Nursalam 2008).

Penelitian lain menjelaskan keterlibatan preceptor dalam program preceptorship sangat dihargai oleh preceptee (85\%). Marks, et al (2013) dalam penelitiannya mendapatkan hasil bahwa preceptor memainkan peran positif dalam hal mengurangi stres, preceptorship berdampak positif pada precepteedalam hal pengembangan pribadi, keterampilan klinik dan komunikasi, peran, dan profesional.Preceptorship sangat menolong perawat baru dalam proses penyesuain diri di tempat kerja atau ruangan baru dalam mem-persiapkan mereka bekerja dengan nyaman dan aman.Selain itu,preceptorship dapat meningkatkan tekhnikal dan teori, menambah pengalaman belajar, meningkatkan kompetensi, dan memberikan tantangan bagi individu, (Walden 2014;Kantar 2012).

Penelitian di Indonesia efektifitas metode preceptor dan mentor dalam meningkatkan kompetensi perawat klinik dapat meningkatkan kompetensi perawat anak dilihat dari motivasi internal, motivasi extrinsik, 
manajemen, kompetensi perawat dan mutu pelayanan (Dermawan 2012). Penelitian lain mengatakan bahwa metode pembelajaran preceptorship dapat meningkatkan kompetensi perawat, dapat menurunkan stres dan kebingungan perawat baru dalam adaptasi (Sulung 2016).

Wawancara dengan Ketua Komite Keperawatan Rumah Sakit Islam Surabaya Jemursari pada tanggal 7 November 2017 bahwa perawat baru yang sudah bekerja selama satu tahun dilakukan assesmen kompetensi oleh asesor Rumah Sakit Islam Surabaya Jemursari dan didapatkan data tahun 2016-2017 sebanyak 37\% perawat baru belum kompeten. Hasil tersebut bisa terjadi karena dipengaruhi oleh beberapa faktor.Kondisi tersebut menunjukkan bahwa sangat perlu diketahui upaya identifikasi faktor yang mempengaruhi pencapaian kompetensi perawat baru di RSIS Jemursari agar dapat membantu memperbaiki pencapaiankompetensi. Salah satu faktor yang mempengaruhi yaitu beban diadakannya metode pembelajaran yang berbasis pengalaman. Metode pembelajaran preceptorship yang berbasis pengalaman dapat digunakan untuk lebih mengembangkan kompetensi perawat (CNA 2004).

Hasil wawancara yang dilakukan kepada preceptor diketahui bahwa pelatihan pelatihan preceptorship belum pernah dilaksanakan sehingga belum memahami tugas sebagai preceptor kepada perawat baru. Tidak ada standar baku dalam proses bimbingan sehingga pelaksanaan bimbingan diruangan berbeda-beda.Sekretaris Clinical Educator (CE) memberikan data pembimbing klinik Rumah Sakit Islam Surabaya Jemursari sebesar 40 orang, pelatihan Clinical Educator sebesar 21 orang $(52,5 \%)$, pelatihan preceptorship sebesar 2 orang $(5 \%)$ dan belum pelatihan 17 orang $(42,5 \%)$.

Rumah Sakit Islam Surabaya Jemursari memberikan masa orientasi terhadap perawat baru selama 3 hari yang dilakukan oleh Koordinator. Hari pertama mengorientasikan perawat baru meliputi orientasi perkenalandenganrekankerja, orientasiruangan/jumlahtempattidur, penjelasantentangstrukturorganisasiruangan, organisasikeperawatan, organisasirumahsakit, orientasijenispelayanan, penjelasan jam kerja dan kedisiplinan ruangan saat bekerja pengenalanalat dan carapengguna-annya. Hari kedua orientasi meliputi penjelasan model asuhankeperawatanprofesional, penjelasan bertelepon dan menerima telepon, pengenalan Standard ProsedurOperasionalruangan, penjelasan unit-unit penunjang pelayanan keperawatan, penjelasanimplementasidoa, proses operan/ 
timbang terima, pelaksanaan penerimaan pasien baru dan pasien pulang, tentang SIM RS. Hari ketiga orientasi meliputiobatobatanemergency, pengenalan dokter yang merawat di ruangan, keselamatanpasien, prosedurcucitangan, penjelasanisi status pasien/ data rekam medis dan penjelasan administrasipasien.

Setelah

orientasitigaharikemudian

dilakukanpengenalankompetensi yang harusdicapai padabulanpertama, bulankedua, dan

bulanketigasesuaidengandimanaperawatbaru tersebutditempatkan. Kompetensi yang dicapaiperawatbaruselamatigabulan rata-rata tiap ruangan $80 \%$.

Perawat baru ditempatkan pada satu tempat sesuai dengan kebutuhan ruangan. Menurut pedoman pengembangan jenjang karir profesional perawat bahwa perawat baru diorientasikan pada empat area yaitu medikal bedah, maternitas, anak dan gawat darurat (Depkes 2006). Sebagai peningkatan mutu pelayanan di RSI Surabaya Jemursari sekarang sedang memagangkan perawat dari ruang rawat inap yang sudah lama di ruang IPI selama tiga bulan.

Manajer SDM Diklat Rumah Sakit Islam Surabaya Jemursari menyadari akan kondisi masa orientasi ini dengan membuat program penyajian kasus dan hasil seminar atau pelatihan setiap dua minggu sekali. Setahun dua kali pegawai baru diprogramkan untuk orientasi klasikal dengan materi sebagai berikut pedoman akhlak sumber daya insani dan dakwah untuk pelanggan, visi, misi, motto RSIS Jemursari, struktur organisasi RSIS Jemursari, hak dan kewajiban pegawai, peraturan perusahaan, K3, KPRS, dan PPI.

Yayasan Rumah Sakit Islam mempunyai dua rumah sakit yang sama dalam mengembangkan visi Yayasan. Peneliti akan melihat bagaimana kompetensi perawat baru di Rumah Sakit Islam Surabaya Jemursari dengan diberikan intervensi dan Rumah Sakit Islam Surabaya sebagai kontrol sesuai dengan yang diberikan sekarang. Peneliti mendapatkan data diRumah Sakit Islam Surabaya bahwa jumlah perawat sebesar 191 orang, jumlah perawat baru sebesar 38 orang, jumlah CE (Clinical Educator) sebesar 42 orang dan sudah mengikuti pelatihan preceptorship sebesar 30 orang $(71,4 \%)$.

Masalah kompetensi serta belum terlaksananya program orientasi dengan motode preceptorship merupakan permasalahan dan membutuhkan penyelesaian/ solusi. Perawat baru membutuhkan informasi yang tepat dan pembelajaran secara terstruktur dengan baik untuk meningkatkan kemampuan dasar. Solusi untuk meningkatkan pencapaian kompetensi agar dapat 
dipenuhi dengan baik adalah dengan pelaksanaan metode pembelajaran preceptorship yang didalamnya terdapat pembinaan serta evaluasi yang berkelanjutan untuk monitoring sikap dan kompetensi perawat oleh preceptor dalam melaksanakan asuhan keperawatan yang sesuai standar. Metode pembelajaran preceptorship memberikan materi kepada preceptor mengajar dan strategi pembelajaran, teori pendidikan, termasuk prinsip-prinsip pendidikan orang dewasa, keterampilan komunikasi, nilai-nilai dan kejelasan peran, resolusi konflik, penilaian kebutuhan belajar individu dan evaluasi kinerja sebagai komponen yang penting untuk memasukkan dalam program preceptorship (Bukhari 2011).

Berdasarkan latar belakang di atas manajemen rumah sakit harus menyusun suatu program orientasi lengkap dan dokumen orientasi yang diperlukan bagi perawat baru. Untuk mengatasi permasalahan/ kesulitan bekerja perawat baru dalam memberikan asuhan keperawatan kepada pasien disesuaikan dengan jenjang karirnya. Orientasi merupakan yang tepat untuk memberikan pembelajaran bagi perawat baru karena menekankan pada kinerja tugas serta implementasinya dengan menggunakan metode preceptorship di unit kerja.

\section{METODE}

Desain penelitian ini menggunakan quasyexperimental.Desain penelitian ini terbagi menjadi dua kelompok yaitu kelompok perlakuan dan kelompok kontrol. Kelompok perlakuan dan kelompok kontrol dilakukan tahap pre-test dengan observasi dua belas kompetensi dasar, sedangkan pada tahap post-test sebelumnya kelompok perlakuan diberikan intervensi pelaksanaan metode preceptorship sesuai dengan modul setelah itu dilakukan observasi dua belas kompetensi dasar. Kelompok kontrol dilakukan post-test observasi dua belas kompetensi dasar sesuai yang sudah dilakukan di RS. Populasi dalam penelitian ini adalah perawat baru di RSI Surabaya Jemursari dan RSI Surabaya. Dalam menentukan sampel dengan menggunakan total samplingdan besar sampel adalah 20 perawat baru untuk masing-masing kelompok perlakuan dan kelompok kontrol. Kriteria inklusi adalah perawat baru $<1$ tahun, pendidikan minimal D3 keperawatan dan belum mengikuti kredensial. Variabel indenpenden dalam penelitian ini adalah metode preceptorship dan variabel dependen adalah pencapaian kompetensi perawat baru. Instrumen yang digunakan untuk mengukur pencapaian kompetensi perawat baru dengan menggunakan lembar check list pencapaian kompetensi berdasarkan kompetensi dasar menurut SKKNI. Data dianalisis dengan 
menggunakan uji Paired Sample t Test, dan uji Independent Sample $t$ Test dengan $\alpha=$ 0,05 .

\section{HASIL PENELITIAN}

Hasil karakteristik perawat baru kelompok perlakuan maupun kelompok kontrol sebagian besar pada rentang usia 20-25 tahun, berjenis kelamin perempuan, masa kerja 1-6 bulan, memiliki tingkat pendidikan Ners (kelompok perlakuan), dan memiliki tingkat pendidikan D3 keperawatan (kelompok kontrol).

Hasil pelaksanaan modul preceptorship meliputi 1) hasil pencapaian kompetensi perawat baru padakelompok perlakuan sebelum intervensi metode preceptorship diberikan dari 12 kompetensi dasar perawat baru sudah kompeten memiliki TTV sebesar 90\% dan memiliki resiko keselamatan sebesar $80 \%$, sedangkan perawat baru belum kompeten memiliki komunikasi interpersonal sebesar 90\%, memiliki pemberian darah dan etika sebesar $80 \%$, dan memiliki rencana asuhan sebesar $70 \%$. Sesudah intervensi metode preceptorship diberikan dari 12 kompetensi dasar perawat baru sudah kompeten memiliki pencegahan infeksi nosokomial, resiko keselamatan, kebutuhan oksigen, TTV, obat aman dan tepat, pemberian darah dan rencana asuhan masing-masing sebesar $100 \%$, sedangkan perawat baru belum kompeten memiliki etika dan komunikasi interpersonal sebesar 20\%, memiliki kebutuhan cairan sebesar $15 \%$ dan memiliki pengkajian dan rawat luka $5 \%$.

Pada kelompok kontrol sebelum diberikan metode sesuai yang sudah dilakukan di RS dari 12 kompetensi dasar perawat baru sudah kompeten memiliki resiko keselamatan sebesar $80 \%$, sedangkan perawat baru belum kompeten memiliki komunikasi interpersonal sebesar $75 \%$, memiliki etika dan rencana asuhan sebesar $60 \%$. Sesudah diberikan metode sesuai yang sudah dilakukan di RS dari 12 kompetensi dasar perawat baru sudah kompeten memiliki resiko keselamatan dan rencana asuhan sebesar $85 \%$ dan memiliki pemberian darah sebesar $75 \%$, sedangkan perawat baru belum kompeten memiliki komunikasi interpersonal sebesar 55\%, memiliki pengkajian, kebutuhan oksigen dan rawat luka $45 \%$.

Tabel 5.3 Distribusi frekuensi pencapaian kompetensi perawat baru sebelum dan sesudah intervensi metode Preceptorship RSIS Jemursari dan RSI Surabaya tanggal 6 Juli-25 Agustus 2018.

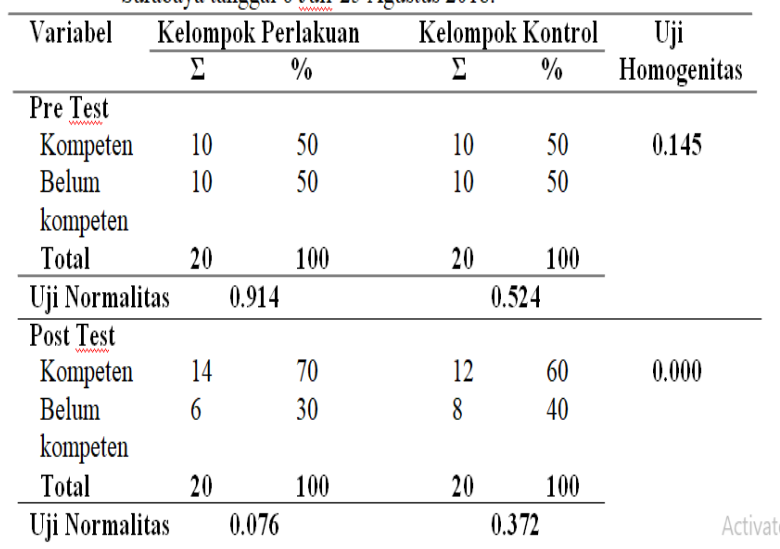


Preceptorship Method To The Achievement Of New Nurse Competencies At Rumah Sakit Islam Surabaya Jemursari

Tabel 5.3 menunjukkan bahwa kelompokperlakuanmaupunkelompokcontrol sebelumintervensi

metodepreceptorshipmemilikidistribusi data yang normal dan homogen, sedangkan sesudah intervensi metodepreceptorshipmemilikidistribusi data yang normal dan tidakhomogen. Distribusipencapaian

kompetensiperawatbarudengankategorikomp etenterjadipeningkatanpada

kelompokperlakuandari $50 \%$ menjadi $70 \%$ dan pada kelompokkontroldari 50\% menjadi $60 \%$.

5.4.3 Analisis perbedaan pencapaian kompetensi perawat baru sesudah
pembelajaran preceptorship antara kelompok perlakuan dan
kelompok kontrol.

Pada kelompok perlakuan sebelum dan sesudahintervensimetodepreceptorshipmemi liki uji delta (selisih) sebesar 12.050 dan nilai signifikansi uji Paired Sample $t$ Test $=$ $0,000(p<0,05)$ yang berarti terdapat pengaruh metode preceptorship terhadap pencapaian kompetensi perawat baru. Pada kelompok kontrol sebelum dan sesudahyang sudah dilakukan RS memiliki uji delta (selisih) sebesar 3.450 dan nilaisignifikansi uji Paired Sample t Test $=0,000(p<0,05)$ yang berarti juga terdapat pengaruh yang sudah dilakukan rumah sakit terhadap pencapaian kompetensi perawat baru. Pencapaian

kompetensiperawatbarusebelumintervensim etode preceptorship pada kelompokperlakuandan kelompok controldiperolehnilaisignifikansiuji Independent Sample $t$ Test $=0,139(p>0,05)$ yang berarti tidakterdapat perbedaan pencapaian kompetensi perawat baru. Sesudah intervensimetode preceptorship pada kelompokperlakuan dan kelompok kontroldiperolehnilaisignifikansiujiIndepend ent Sample $t$ Test $=0,000(p<0,05)$ yang berarti terdapat perbedaan pencapaian kompetensi perawat baru. Hal inimenunjukkanterdapatpengaruh yang bermaknadarimetode preceptorship terhadap pencapaian kompetensi perawat baru.

\section{SIMPULAN}

Kesimpulan hasil pelaksanaan metode preceptorship dapat meningkatkan kompetensi, meskipun masih di dapatkan sebagian perawat baru belum kompeten dalam mencapai kompetensi yaitu melakukan pengkajian, memberikan kebutuhan cairan dan elektrolit, melakukan rawat luka, etika dalam keperawatan dan komunikasi 
interpersonal. Pencapaian kompetensi yang belum seluruhnya kompeten dipengaruhi oleh usia, jenis kelamin, masa kerja, dan pendidikan. Hasil kompetensi yang meningkat paling baik adalah melakukan pemberian darah.

\section{SARAN}

Rumah sakit untuk meningkatkan kualitas SDM (preceptor) dan kompetensi perawat baru, maka perlu diberikan pelatihan terhadap CE/ preceptor.

Rumah sakit dapat menyusun program preceptorship yang berfokus pada perawat baru sehingga dapat mengevaluasi kompetensi perawat baru selama masa orientasi tiga bulan, enam bulan sampai satu tahun dengan melakukan perbaikan, perawat harus mempertahankan kompetensi yang berkualitas dan meningkatkan kinerja perawat sesuai dengan standar yang telah disepakati.

\section{REFERENSI}

Billay, D., Myrick, F., \& Yonge, O. (2015). Preceptorship and the Nurse Practitioner Student: Navigating the Liminal Space.Journal of Nursing Education, 54(8), 430-437. https://doi.org/10.3928/0148483420150717-02

Dermawan, D. (2012) 'Mentorship dan preceptorship dalam keperawatan',Profesi, 8 (September), pp.1-9.

http://doi.org/ejournal.stikespku.ac.id/ index.php/profesi/ article/download/9/7

Foley, V., Myrick, F. and Yonge, O. (2012)
'Generational Clashpoints in Nursing Preceptorship', Journal of Nursing Education, 51(10), pp. 556-562. doi: 10.3928/01484834-20120820-04.

Harianja, M 2014. Pengaruh program orientasi keperawatan terhadap peningkatan kompetensi perawat baru di Siloam Hospital, Digilib esa unggul.< htt:// digilib esa unggul.ac.id>

Hariyati, ST 2015. Proses kredensial dan rekredential keperawatan I. Diktat pelatihan. Jakarta.

Kepmen Nakertrans RI, 2007. Tentang penetapan jasa kesehatan, Nomor: Kep.148/Men/III.

Lina D. Kantar, EDD/CI, RN, 2012. Clinical practice of Nurse Graduates in Libanon: Challenges and Perspectives Trough the Eyes of Preceptors. J Contin Educ Nurs; 43(11):518-528

Marks-Maran, D.et al. 2013. A preceptorship programme for newly qualifeld nuerses: A study of preceptees perceptions, Nurse Education Today. Elsevier Ltd, 33(11),pp.1428434.doi:10.1016/j.nedt.20 12.11.013.

Marquis, L Bessie \& Huston, 2010. Kepemimpinan dan menejemen Keperawatan. EGC: Jakarta

Notoatmojo, soekidjo, 2012. Promosi kesehatan dan perilaku kesehatan, Jakarta: Rineka cipta.

Nursalam, 2015. Manajemen Keperawatan: Aplikasi dalam praktik Keperawatan Profesional, Jakarta Salemba Medika.

Qaboos, \& Sultan, 2014. Challenges and strategies for building and maintaining efective preeceptor-preceptee relationship among nurses.

Saragih, 2011. Hubungan program preceptorship dan karakteristik perawat dengan proses adaptasi perawat baru di $P K S C$, RSB, dan RSPI,tesis, Universitas 
Preceptorship Method To The Achievement Of New Nurse Competencies At Rumah Sakit Islam Surabaya Jemursari

Indonesia, Jakarta.

Staykova, M. P., Huson, C. and Pennington, D. (2013). 'Empowering Nursing Preceptors to Mentoring Undergraduate Senior Students in Acute Care Settings',Journal of Professional Nursing, 29(5), pp. 32-36. doi:

Sulung, N. (2016). Efektifitas metode preseptor dan mentor dalam meningkatkan kompetensi perawat klinik.Ipteks Terapan, 9(2), 224-235.

Susan Batory, 2014. Nursing role transition preceptorship, Walden University.

$\mathrm{Yu}$ Cheng, Ching, 2014. New graduate nurses clinical competence, clinical stress, and intention to leave a longitudinal study in Taiwan. 